\title{
Surveillance of influenza A H1N1 2009 among school children during 2009 and 2010 in São Paulo, Brazil
}

\author{
Sandra Baltazar Guatura ${ }^{[1]}$, Aripuana Sakurada Aranha Watanabe ${ }^{[1]}$, Clarice Neves Camargo ${ }^{[1]}$, \\ Ana Maria Passos ${ }^{[1]}$, Sheila Negrini Parmezan ${ }^{[1]}$,Tatiane Karen Cabeça Tomazella ${ }^{[1]}$, Emerson Carraro ${ }^{[1]}$, \\ Janete Kamikawa ${ }^{[1]}$, Celso Granato ${ }^{[1]}$ and Nancy Bellei ${ }^{[1]}$
}

[1]. Laboratório de Virologia Clínica, Disciplina de Infectologia, Departamento de Medicina, Universidade Federal de São Paulo, São Paulo, SP.

\section{ABSTRACT}

Introduction: Influenza A H1N1 2009 is associated with a high morbidity rate among children around the world, including Brazil. This survey was conducted on samples of symptomatic children ( $\leq 12$ years) to investigate the influenza virus as the etiological agent of respiratory infections in a day care school in a health facility during the first and second pandemic wave of H1N1 (2009-2010) in São Paulo, Brazil. Methods: Influenza infections were determined by real-time PCR in 34\% (47/137) of children with a median age of 5 years ( 8 months - 12 years), from June to October 2009 and in $16 \%$ (14/85) of those with median age of 6 years (1-12 years), from March to November 2010. Results: In general, most positive cases (64\%) occurred in children aged 5-12 years, this age group was significantly the most affected $(39.8 \%, p=0.001, \mathrm{OR}=8.3, \mathrm{Cl} 95 \% 1.9-36.9)$. Wheezing was reported by $31 \%(19 / 61)$ and dyspnea by $23 \%(14 / 61)$ of the studied patients. An outbreak of influenza H1N1 with an attack rate of $35.7 \%$ among children (median age 6 years) was documented in April 2010, before the vaccination campaign against the pandemic virus was extended for children up to 5 years in Brazil. Conclusions: Therefore, the study reinforces the recommendation to immunize school children to reduce the incidence of the disease.

Keywords: Influenza H1N1. PCR-RFLP. Surveillance. Subtyping.

\section{INTRODUCTION}

Influenza A has been pointed as an important pathogen in childhood morbidity and children have an important role in virus transmission in the community. Taking into consideration the post pandemic situation, knowledge of influenza epidemiology in pediatric population is critical for directing further interventions ${ }^{1}$.

The impact of influenza virus in children was described long ago, with a seasonal average duration of 6-8 weeks, starting among school children and moving to adults. The role of children in the spread of this virus is clear, and it has been reported in many epidemiological studies $^{2}$.

Esposito et al. ${ }^{3}$ studied the impact of influenza virus in healthy children up to 15 years old and their families, showing that a change in people's habits is needed to help in the prevention from virus infection and the expansion and acceptance of the influenza vaccination program ${ }^{3}$.

Another study conducted in São Paulo, Brazil, among children and young adults described a higher incidence in children younger than 14 years and suggested that vaccination against influenza virus is efficient and necessary every year ${ }^{4}$.

The purpose of this study was to investigate the influenza virus as the etiological agent of respiratory infections among symptomatic day care school children up to 12 years in São Paulo City from 2009 to 2010 .

\footnotetext{
Address to: Dra. Nancy Bellei. Lab. Virologia Clínica/Discip Infectologia/UNIFESP. Rua Pedro de Toledo 781/15 andar, Vila Clementino, 04039-032 São Paulo, SP, Brasil. Phone/Fax: 5511 5081-5394

e-mail: nbellei@uol.com.br

Received in 08/11/2011

Accepted in 13/03/2012
}

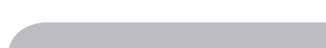

\section{METHODS}

Symptomatic children, attending in a day care and school, with acute respiratory infection of probable viral etiology were enrolled by a pediatrician after the consent form was signed by the parents or guardians. The inclusion criterion was: children up to 12 years of age presenting fever up to 7 days. Overall, 222 nasal swabs samples were collected. RNA was extracted according to the manufacturer's instructions (QIAamp Viral RNA extraction kit; QIAGEN, Valencia, CA). It is noteworthy that the children's are attending in a location that is both day care and school, which results in a constant contact between children of different ages.

Reverse transcription polymerase chain reaction (RT-PCR) was conducted for amplification of a segment of $M$ and NS gene from influenza $A$ and $B$, respectively. All samples with positive tests for influenza A H1N1 were confirmed by real-time RT-PCR, according to Centers for Disease Control and Prevention (CDC) protocol ${ }^{5}$.

PCR products were visualized by electrophoresis on a $2 \%$ agarose gel stained by ethidium bromide according to the molecular weight, $698 \mathrm{bp}$ and $108 \mathrm{pb}$ for influenza $A$ and $B$, respectively. Subtyping of influenza A positive samples was performed by restriction fragment length polymorphism (RFLP), in which 10uL of unpurified PCR products were digested with Hind III and Scal enzymes (New England Biolabs, Beverly, MA) in two separate reactions, according to the manufacturer's instructions, Digested fragments were visualized by ethidium bromide staining following electrophoresis on a $2 \%$ agarose gel. Influenza A subtype H3N2 was indicated by HindIII amplicon cleavage, and influenza A subtype H1N1 was indicated by Scal amplicon cleavage, as previously described ${ }^{6}$.

Statistical analysis consisted of chi-squared test and nonconditional logistic regression for the comparison of categorical variables. Results were presented as odds ratio (OR), the respective $95 \%$ confidence interval $(\mathrm{Cl})$ and $p$ value with a significance level of 
$p<0.05$. All reported values are two-tailed. And all data were entered into and analyzed by using SPSS version 11.0 (SPSS Inc., Chicago, IL, USA).

\section{Ethical considerations}

This study was approved by the Ethics Committee at the Federal University of São Paulo (UNIFESP) in compliance with the provisions of National Board of Health Resolution n. 196 of October 10, 1996, and all participants gave informed consent. Ethics Committee number 0670/08.

\section{RESULTS}

Of all 222 enrolled children, 116 (52.3\%) were female and 106 (47.7\%) were male. Age ranged from 1 month to 12 years, mean 4.2 years and median 3.5 years.

Overall, 30.2\% (67/222) influenza cases were detected. In 2009 $34 \%(47 / 137)$ of the samples were positive for influenza virus and $23.5 \%$ (20/85) in 2010. Statistical analysis of influenza virus occurrence between 2009 and 2010 showed no difference ( $p=0.12$ ). Regarding the different influenza subtypes, in 2009, 25\% (34/137) of all samples were positive for H1N1 2009 and 9\% (13/137) were positive for seasonal influenza (H3N2). In 2010, 16\% (14/85) were positive for H1N1, and $7 \%(6 / 85)$ for influenza $\mathrm{B}$; no H3N2 cases were detected in this year
(Figure 1). There was a significant decreasing trend in H3N2 cases from 2009 to 2010 ( $p=0.05)$.

The median age of positive and negative cases in 2009 year was respectively five and three years old. In 2010 the median age of positive and negative cases was respectively six and three years old (Table 1).

Fifteen per cent (5/34) of 2009 positive cases had been vaccinated for seasonal influenza and $14 \%$ (2/14) of 2010 positive cases had been vaccinated against influenza H1N1 2009. Out of the pandemic subtype cases, one child aged 1 year old was enrolled five days after vaccination and the other aged 3 years old three days after.

Five (35.7\%) out of the four-teen positive cases of pandemic influenza detected in 2010 were from an outbreak occurred in April among unvaccinated classmates. The nine remaining cases were also confirmed as influenza A H1N1 2009, but occurred outside of the described outbreak period. Considering influenza H1N1, there was an upward trend in the frequency of positive cases according to age (Figure 2).

Indeed, the majority of positive cases (64\%) occurred in the 5-12 age group which had also the highest frequency of infection among all groups [39.8\%, $\mathrm{p}=0.001, \mathrm{OR}=8.3, \mathrm{Cl}$ (95\% 1.9 -36.9)] (Table 2).

The most frequently reported symptoms were coryza $89.5 \%$ (60/67), cough $91 \%(61 / 67)$, fever $83.6 \%(56 / 67)$, sore throat $42 \%$ (28/67), wheezing $31.3 \%(21 / 67)$, and dyspnea $21 \%(14 / 67)$.

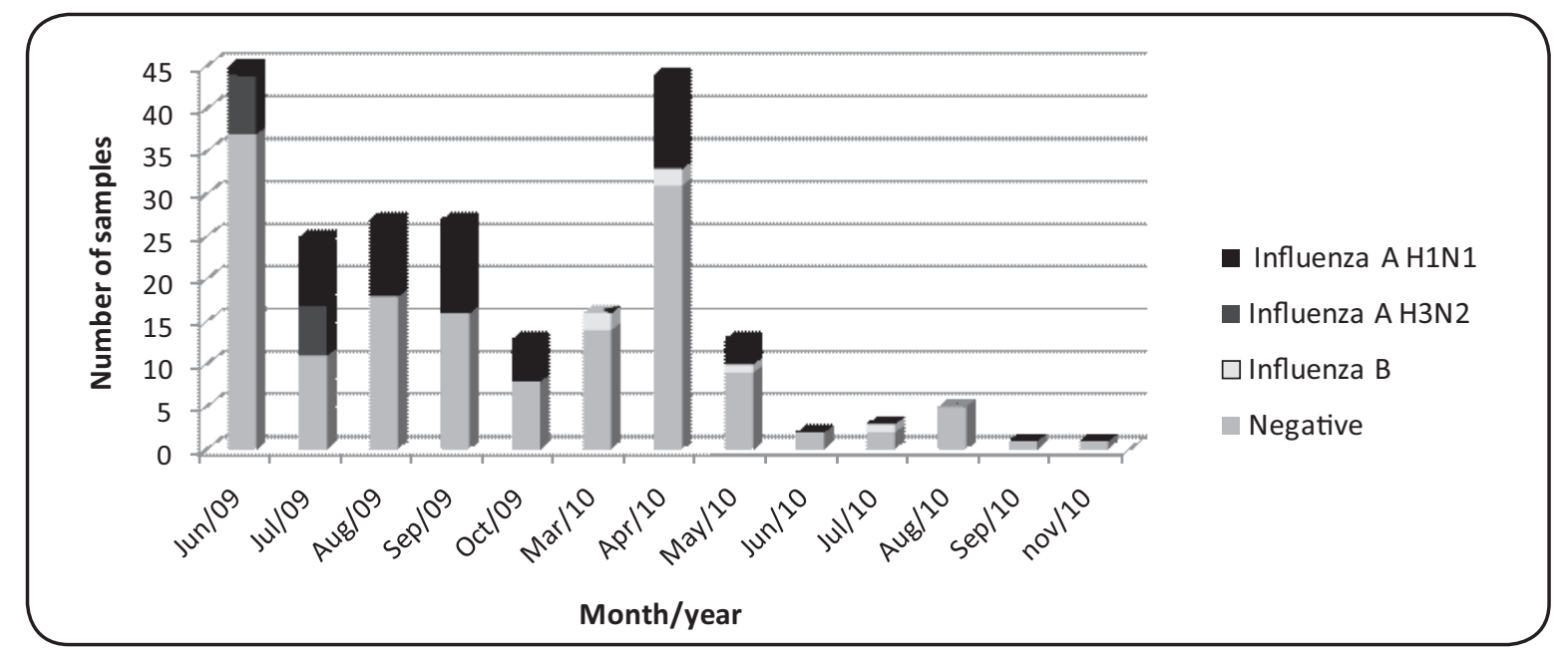

FIGURE 1 - Occurrence of influenza A H1N1/H3N2 and influenza B in 2009 and 2010.

TABLE1 - Influenza A positive and negative cases according to age.

\begin{tabular}{|c|c|c|c|c|c|c|c|c|}
\hline \multirow[b]{2}{*}{ Age group } & \multicolumn{4}{|c|}{2009} & \multicolumn{4}{|c|}{2010} \\
\hline & positive & $\%$ & negative & $\%$ & positive & $\%$ & negative & $\%$ \\
\hline$<1$ & 2 & 4.3 & 13 & 14.4 & 0 & 0 & 12 & 17.0 \\
\hline$\geq 2<5$ & 11 & 23.4 & 22 & 24.0 & 4 & 28.6 & 23 & 32.4 \\
\hline$\geq 5 \leq 12$ & 30 & 63.8 & 34 & 37.9 & 9 & 64.3 & 26 & 36.6 \\
\hline Total & 47 & 100.0 & 9 & 100.0 & 14 & 100.0 & 71 & 100.0 \\
\hline
\end{tabular}




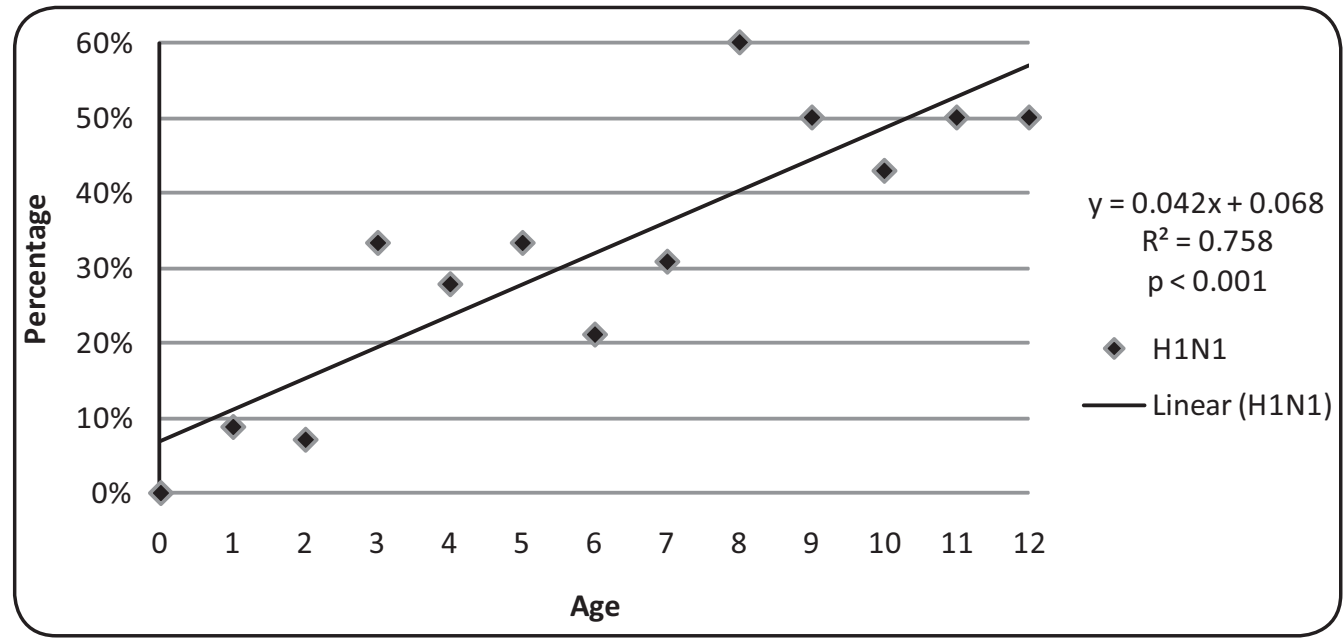

FIGURE 2 - Frequency of H1N1 cases in 2009 and 2010 according to age.

TABLE 2 - Non-conditional logistic regression of influenza H1N1 frequency according to age group.

\begin{tabular}{lcccccc}
\hline Age group & H1N1 $(\mathbf{n})^{*}$ & $\%$ & OR & Cl 95\% & p & Total \\
\hline$<1$ & 2 & 7.4 & 1 & - & - & 27 \\
$\geq 1$ e $<2$ & 5 & 13.5 & 2.0 & $0.4-10.9$ & 0.45 & 37 \\
$\geq 2$ e $<5$ & 15 & 25.0 & 4.2 & $0.9-19.7$ & 0.07 & 60 \\
$\geq 5$ e $\leq 12$ & 39 & 39.8 & 8.3 & $1.9-36.9$ & 0.01 & 98
\end{tabular}

OR: Odds ratio; Cl: confidence interval; ${ }^{*}$ Chi-squared test: $p=0.001$.

\section{DISCUSSION}

Our study was carried out during the influenza season in São Paulo (June to October) in 2009, including the first wave of 2009 pandemic influenza, and in 2010 (March - November). São Paulo is the most populated city in Brazil and influenza H1N1 2009 had a great impact on morbidity and mortality during $2009^{1}$.

Available data of influenza circulation among children generally come from hospital surveillance and there is a lack of information about influenza infections among community young children. Youngest children were the most affected by H1N1 2009, according to official surveillance ${ }^{7}$. Children up to 24 months are at highest risk of hospitalization and death ${ }^{8}$. Children played a major role in the influenza virus transmission and are the main introducers of influenza into households ${ }^{9,10}$.

The recent $C D C$ influenza vaccination recommendations extended protection to the entire population after the pandemic first wave to reduce overall influenza infection rates ${ }^{11}$.

In our study, the two vaccinated positive H1N1 children were not considered to be immunized against influenza once they had been recently vaccinated and protective antibody titers are usually achieved after two weeks of vaccination ${ }^{12}$.

Overall, children attending the day care school center obtained a $25 \%$ rate of H1N1 2009, although the school was closed after winter vacations during the pandemic peak in 2009. In 2010, the $16 \%$ rate shows a decrease of the pandemic virus which can be attributed to the large immunization program actions from April to June.
Official recommendations included children up to 2 years and, in a second phase, were extended to those up to 5 years. In this regard, the $36 \%$ outbreak attack rate during mid-April, median age 6 years old, occurred among non-immunized patients. In addition, the highest infection rates were found in the 5-12 years age group.

Few studies have investigated H1N1 2009 infection in school aged children. Wu et al. ${ }^{13}$ described an overall attack rate of $10.7 \%$ and $43.4 \%$ of H1N1 2009 among those aged 5-14 years, the age group with larger incidence of pandemic virus. Accordingly, Bagdure et al. found an H1N1 2009 infection rate of 38\% among children aged 5-9 years, patients in the Pediatric Intensive Care Unit in Denver, USA ${ }^{14}$. All these data are consistent with the findings in our study.

Torres et al. ${ }^{15}$ described a frequency of 45\% of H1N1 2009 among Chilean young adults (5-18 years). Echavarria et al. ${ }^{16}$ described that $43 \%$ of H1N1 2009 infected patients in Argentina were part of the 5-18 years age group. Raboni et al. (2010) reported a 58\% rate in children aged 5-14 years in Curitiba, Brazili ${ }^{17}$.

Before the emergence of H1N1 2009 around the world, other influenza subtypes circulated, mainly H3N2 and, in a smaller proportion, seasonal $\mathrm{H} 1 \mathrm{~N} 1^{18}$. After the establishment of the pandemic virus, the circulation of other subtypes strongly decreased ${ }^{19}$.

The rates of detection of the different influenza virus subtypes demonstrated that the wave of the pandemic H1N1 virus inhibited the spread of $\mathrm{H} 3 \mathrm{~N} 2$ in the two studied years.

We verified a strong association between the prevalence of $\mathrm{H} 1 \mathrm{~N} 1$ 2009 and the age group of 5 to 12 years. These Brazilian data are in agreement with data from other studies that indicate at high level of circulation of H1N1 2009 influenza viruses among older children in the community4.

In the year 2010, the Brazilian Immunization Program vaccinated children up to 5 years against pandemic influenza. In 2011, the new recommendations consisted of a trivalent vaccine for all three subtypes including the H1N1 2009, H3N2 and influenza B for the elderly, pregnant women and children up to 24 months.

The H1N1 2009 virus was frequently identified as the etiological agent of respiratory infection among symptomatic day care schoolchildren in this study. Overall, these data reinforce the need to 
immunize children against all influenza subtypes every year, especially older children who play an important role in virus transmission in the community.

\section{CONFLICT OF INTEREST}

The authors declare that there is no conflict of interest. Despite the partial supporting of Sanofi Aventis Pasteur the authors state that the results of the present study are independent of any company interest.

\section{FINANCIAL SUPPORT}

This work was partially supported by Sanofi Aventis Pasteur; Vaccine Division of Sanofi-Aventis.

\section{ABSTRACT IN PORTUGUESE}

\section{Vigilância de influenza A H1N1 2009 entre crianças em idade escolar durante os anos de 2009 e 2010 em São Paulo, Brasil}

Introdução: Influenza A H1N1 2009 está associado com uma alta taxa de morbidade entre crianças ao redor do mundo, incluindo o Brasil. Esta pesquisa foi realizada em amostras de crianças sintomáticas ( $\leq 12$ anos) em uma creche escola para filhos de funcionários do hospital durante a primeira e segunda onda pandêmica (2009-2010) em São Paulo, Brasil. Métodos: Infecções pelo vírus influenza foram determinadas por PCR em tempo real em 34\% (47/137) em crianças com idade mediana de 5 anos (8 meses - 12 anos), entre junho e outubro de 2009 e em $16 \%$ (14/85) daquelas com mediana de idade de 6 anos (1-12 anos), de março a novembro de 2010. Resultados: Em geral, a maioria dos casos positivos (64\%) ocorreu em crianças com idade entre 5-12 anos, esta faixa etária foi significativamente a mais afetada (39,8\%, $\mathrm{p}=0,001, \mathrm{OR}=8,3, \mathrm{Cl} 95 \%: 1,9-36,9)$. Chiado foi relatado em $31 \%$ (19/61) e dispnéia em $23 \%$ (14/61) dos pacientes estudados. Um surto de gripe H1N1 com uma taxa de ataque de $35,7 \%$ entre as crianças (mediana de idade de 6 anos) foi documentado em abril de 2010, antes da extensão da campanha de vacinação contra o vírus pandêmico para crianças até 5 anos no Brasil. Conclusões: Portanto, neste estudo reforça a recomendação para imunizar crianças em idade escolar para reduzir a incidência da doença.

Palavras-chaves: Influenza H1N1. PCR-RFLP. Vigilância. Subtipagem.

\section{REFERENCES}

1. Oliveira W, Carmo E, Penna G, Kuchenbecker R, Santos H, Araujo W, et al. Surveillance Team for the pandemic influenza A(H1N1) 2009 in the Ministry of Health. Pandemic H1N1 influenza in Brazil: analysis of the first 34,506 notified cases of influenza-like illness with severe acute respiratory infection (SARI). Euro Surveill 2009; 14:pii:19362.

2. Glezen WP, Couch RB, Maclean RA, Payne A, Baird JN, Valbona C, et al. Interpandemic Influenza in the Houston Area. N Engl J Med 1978; 298:587-592.
3. Esposito S, Gasparini R, Bosis S, Machisio P, Tagliabue C, Tosi S, et al. Clinical and socio-economic impact of influenza and respiratory syncytial virus infection on healthy children and their households. Clin Microbiol Infect 2005; 11:933-936.

4. Paiva TM, Ishida MA, Hanashiro KAY, Scolaro RM, Gonçalves MG, Benega MA, et al. Outbreak of Infleunza type A (H1N1) in Iporanga, São Paulo state, Brazil. Rev Inst Med Trop São Paulo 2001; 43:311-315.

5. Center for Disease Control and Prevention (CDC) protocol of real time RT-PCR for influenza A (H1N1) [Internet]. World Health Organization. [Cited 2011 June 15]Available from: http://www.who.int/csr/resources/publications/swineflu/ realtimeptpcr/en/index.html.

6. Carraro E, Watanabe AS, Neto DF, Granato CF, Bellei NC. Influenza detection and subtyping by reverse transcriptase polymerase chain reaction-restriction fragment length polymorphism for laboratory surveillance in Brazil. Diagn Microbiol Infect Dis 2008; 60:445-447.

7. Advisory Committee on Immunization Practices (ACIP) [Internet]. Center for Disease Control and Prevention (CDC); 2009. [Cited 2011 August 29] Available from: http:// www.cdc.gov/vaccines/recs/ACIP/default.htm.

8. Harper SA, Fukuda K, Uyeki TM, Cox NJ, Bridges CB. Prevention and con trol of influenza: recommendations of the Advisory Committee on Immunization Practices (ACIP). Centers for Disease Control and Prevention (CDC) Advisory Committee on Immunization Practices (ACIP). MMWR Recommend Rep 2004; 53(RR-6):1-40. Erratum in: MMWR Recomm Rep 2004; 53:743.

9. Longini Jr IM, Koopman JS, Monto AS, Fox JP. Estimating household and community transmission parameters for influenza. Am J Epidemiol 1982; 115:736-751.

10. Viboud C, Boëlle PY, Cauchemez S, Lavenu A, Valleron AJ, Flahault A, Carrat F. Risk factors of influenza transmission in households. Br J Gen Pract 2004; 54:684-689.

11. Shuler $\mathrm{CM}$, Iwamoto $\mathrm{M}$, Bridges $\mathrm{CB}$, et. al. Vaccine effectiveness against medically attended, laboratory-confirmed influenza among children aged 6 to 59 months, 2003-2004. Pediatrics 2007; 119:e587- e595.

12. World Health Organization (WHO). Vaccines [Internet]. [Cited 2011 June 16] Available from: http://www.who.int/topics/vaccines/en/.

13. Wu JT, Ma ES, Lee CK, Chu DK, Ho PL, Shen AL, et al. Cowling BJ, Malik Peiris JS. The infection attack rate and severity of 2009 pandemic H1N1 influenza in Hong Kong. Clin Infect Dis 2010; 51:1184-1191.

14. Bagdure D, Curtis DJ, Dobyns E, Glodé MP, Dominguez SR. Hospitalized children with 2009 pandemic influenza A (H1N1): comparison to seasonal influenza and risk factors for admission to the ICU. PLoS One 2010; 5:e15173.

15. Torres JP, O'Ryan M, Herve B, Espinoza R, Acuña G, Mañalich J, et al. Impact of the novel influenza $A$ (H1N1) during the 2009 autumn-winter season in a large hospital setting in Santiago, Chile. Clin Infect Dis. 2010; 50:860-868.

16. Echavarria M, Querci M, Marcone D, Videla C, Martinez A, Bonvehi P, et al. Pandemic (H1N1) 2009 cases, Buenos Aires, Argentina. Emerg Infect Dis 2010; 16:311-313.

17. Raboni SM, Stella V, Cruz CR, França JB, Moreira S, Gonçalves L, et al. Laboratory Diagnosis, Epidemiology, and Clinical Outcomes of Pandemic Influenza A and Community Respiratory Viral Infections in Southern Brazil. J Clin Microbiol 2011; 49:1287-1293.

18. Center for Disease Control and Prevention (CDC). Influenza Activity-United States and Worldwide, 2007-08 Season. Morbid Mortal Wkly Rep 2008; 57: 692-697.

19. Center for Disease Control and Prevention (CDC). Update: Influenza Activity - United States, August 30 - October 31, 2009. Morbid Mortal Wkly Rep 2009; 58:1236-1241. 